\title{
Coyote Predation Effects on White-Tailed Deer Fawns
}

\author{
Lauren N. Watine, William M. Giuliano \\ Department of Wildlife Ecology and Conservation, University of Florida, Gainesville, USA \\ Email:*docg@ufl.edu
}

How to cite this paper: Watine, L.N. and Giuliano, W.M. (2016) Coyote Predation Effects on White-Tailed Deer Fawns. Natural Resources, 7, 628-643.

http://dx.doi.org/10.4236/nr.2016.711050

Received: July 27, 2016

Accepted: November 14, 2016

Published: November 17, 2016

Copyright $\odot 2016$ by authors and Scientific Research Publishing Inc. This work is licensed under the Creative Commons Attribution International License (CC BY 4.0).

http://creativecommons.org/licenses/by/4.0/

(c) (i) Open Access

\begin{abstract}
Coyotes (Canis latrans) are a relatively new predator to the southeastern United States, and may be negatively impacting white-tailed deer (Odocoileus virginianus, hereafter, deer) populations. Our objectives were to evaluate the impacts of coyotes on deer fawns by assessing deer fawn survival and cause-specific mortality, and gain an understanding of factors affecting fawn survival and coyote predation. We captured and radio collared 30 fawns in the Red Hills region of Florida and Georgia, USA (20122013). Fawns were monitored for 12 weeks for survival and cause-specific mortality, and we quantified habitat and environmental characteristics of birth sites. Predation ( $\mathrm{n}=19 ; 95 \%)$ was the leading cause of fawn mortality $(\mathrm{n}=20 ; 67 \%)$, with coyote predation $(n=14 ; 74 \%)$ being the most important type of predation. Survival rates for all fawns were greater $(\mathrm{P}=0.048)$ where coyotes were removed compared to nonremoval sites, with $50 \%$ and $25 \%$ of fawns surviving to 12 weeks on coyote-removal and non-removal sites, respectively. Survival rates of fawns ultimately predated by coyotes were greater $(\mathrm{P}=0.096)$ on coyote-removal than non-removal sites, with $40 \%$ and $50 \%$ of fawns predated by coyotes within 12 weeks on coyote-removal and non-removal sites, respectively. Survival of all fawns and those predated by coyotes was lower when fawns were born at sites with greater hardwood basal area, total basal area, and canopy closure; and survival improved if born in or near hardwood, natural pine, and managed (planted) pine cover types. Increased canopy cover within 10 $m$ of the birth site was selected by adult females for birth sites of all fawns and those that were predated by coyotes. Compared with fawns that lived, all dying fawns and those predated by coyotes had less shrub cover within $5 \mathrm{~m}$ and less grass cover at and within $10 \mathrm{~m}$ of the birth site. Coyote removal increased fawn daily survival rates, and habitat played a role in fawn survival.
\end{abstract}

\section{Keywords}

Canis latrans, Coyote, Odocoileus virginianus, Predation, Survival, White-Tailed Deer 


\section{Introduction}

The relatively recent colonization of coyotes (Canis latrans) in the southeastern United States may be negatively influencing white-tailed deer (Odocoileus virginianus) populations. Although coyote numbers are increasing throughout the Southeast, and studies have documented the potential for coyote predation to negatively affect deer populations, little quantitative evidence for coyote impacts on deer exists, and less is known about the effects of coyotes on deer in Florida and adjacent areas [1] [2] [3]. The climate, weather, vegetation, and fauna in these areas differ greatly from the coyote's historic western range and much of the remainder of their southeastern U.S. distribution, possibly affecting coyote foraging behavior and effects on deer [4] [5]. In addition, throughout much of Florida and parts of adjacent states, deer populations exhibit lower recruitment and productivity due to naturally poor habitat conditions [6]. Under such poor conditions, even small increases in predation may have dramatic effects on deer populations.

Deer management practices have often focused on the control of predators to increase deer populations [7] [8] [9] [10]. However, such programs may have few longterm effects on coyote populations [11] [12] [13] [14], and little quantitative evidence exists regarding coyote-removal effects on deer populations [10]. Most research on the effects of coyote removal suggests equivocal or site-dependent effects. In addition, most studies fail to link directly coyote removal and fawn survival [1] [7] [15] [16] [17]. Further, habitat structure may be a significant determinant of deer fawn survival and recruitment in areas where coyotes are found [18] [19] [20]. Therefore, it is essential to understand what factors are most important to coyote predation success, and thus deer fawn survival, to inform effective deer management.

We examined deer fawn survival and cause-specific mortality, including the relative importance of coyotes, in the Red Hills region of Florida and Georgia, where knowledge of the role of habitat on coyote predation success is lacking. Additionally, to understand factors affecting fawn survival in the context of coyote predation, we examined the importance of microhabitat (e.g., shrub cover), landscape (e.g., distance to road), and environmental (e.g., rainfall) characteristics in and around fawn birth sites.

\section{Study Areas}

Fawn survival was assessed on 2 sites in the Red Hills region of South Georgia and North Florida: Rosemary Plantation (RP) and Dixie/Pinion Point Plantation (DPPP; adjacent properties that comprised one study area). This area is characterized by red clay soils, rolling hills, and largely undeveloped plantation lands [21].

Rosemary Plantation is located in Thomas County, Georgia. This 2,400 ha plantation is primarily composed of upland pine habitat with hardwood bottoms, and borders the Ochlockonee River. Dixie Plantation is located in Madison County, Florida and Pinion Point Plantation is in Brooks County, Georgia. Dixie/Pinion Point borders the Aucilla River, is composed of similar habitats as RP, and is approximately 3000 ha. Both sites are managed specifically for northern bobwhite (Colinus virginianus). Each plantation 
provides recreational hunting opportunities for northern bobwhite, mourning dove (Zenaida macroura), waterfowl, wild turkey (Meleagris gallopavo), feral hog (Sus scrofa), and deer.

During the past 10 years, 0 - 10 coyotes/year were haphazardly removed by hunting, shooting, and trapping on each site. During the study, half of each study site was randomly selected, and landowners ceased coyote removal during 2012-2013. Approximately 10 coyotes were removed each year (2012-2013) on the half of each study area where coyote removal continued.

\section{Materials and Methods}

\subsection{Fawn Survival}

Across both sites and years, we captured adult female deer by darting (X-Caliber, PneuDart, Inc., Williamsport, PA, fitted with ATN PS22-CGT night vision scope adapters [American Technologies Network Corporation, San Francisco, CA]) from tree stands over bait (corn), and from vehicles via spotlighting [3] from February-April, 2012-2013. Captured deer were fitted with vaginal implant transmitters (VIT; Model 3930, Advanced Telemetry Systems, Isanti, MN), following [22], except that we left a protruding antenna. Each deer received an individually numbered ear-tag and radio-collar with a mortality switch on a 4-hour delay and activity switch on a 1-hour delay (Model 2510 B, Advanced Telemetry Systems, Isanti, MN). Deer handling procedures followed [3].

Signals from VITs were monitored every 3 - 12 hours for birth events from the end of the capture season through August each year (2012-2013), leading to the capture of 30 fawns. We provided adult females and fawns a minimum of 3 hours for cleaning and bonding before capturing fawns, to minimize the chances of fawn abandonment. Each fawn was fitted with an expandable collar transmitter with a 4-hour delay mortality switch (Model 4210; Advanced Telemetry Systems, Isanti, MN). Fawn capture and handling procedures followed [3].

Most fawn mortality occurs within the first 12 weeks of life [23] [24]. For this reason, fawns were located and monitored for mortality 2 - 4 times/day until 12 weeks of age, allowing us to recover fawn carcasses quickly and reduce loss and deterioration of evidence that might aid in determining cause of mortality. We considered subcutaneous hemorrhaging, partial or total consumption of the carcass, and caching behavior [3] to determine predation mortality. Cache characteristics, tracks, scat, other evidence at the recovery site, and carcass location in relation to the fawn's home range were used to determine the predator species responsible [25] [26] [27]. Fawn carcasses (i.e., bite wounds around head and neck) and radio transmitters (i.e., hard surfaces of transmitters) were swabbed for DNA evidence, such as saliva, to aid in positive identification of predator species.

All research and animal welfare protocols were reviewed and approved: University of Florida Animal Research Permit (003-11 WEC), Florida Fish and Wildlife Conservation Commission Research Permit (SPGS-11-68), and Georgia Department of Natural Resources Research Permit (29-WBH-12-153). 


\subsection{Habitat Measurements}

We recorded fawn birth date, and microhabitat, landscape, and environmental characteristics at birth (i.e., VIT) sites. These characteristics were also recorded at a paired random site, which was located at a random distance $(30-200 \mathrm{~m})$ and direction, in the same cover type patch [28] as the birth site. To characterize microhabitat characteristics, we recorded grass cover, total herbaceous cover, shrub cover, vegetation height, basal area, and canopy closure at the site and within $5 \mathrm{~m}$ and $10 \mathrm{~m}$ of the site. Grass and total herbaceous cover (\%) were visually estimated in $91-\mathrm{m}^{2}$ plots (1 at the site, $45 \mathrm{~m}$ from the site in the cardinal directions, and $410 \mathrm{~m}$ from the site in the cardinal directions; Figure 1). Shrub (woody vegetation $\leq 2 \mathrm{~m}$ ) cover (\%) was determined along 2 perpendicular 20-m transects centered on the site using the line intercept method [29]. Vegetation height (herbaceous or shrub; $\mathrm{cm}$ ) was determined by measuring the height of the tallest vegetation intercepting the 2 perpendicular transects at the site, $5 \mathrm{~m}$ from the site in the cardinal directions, and $10 \mathrm{~m}$ from the site in the cardinal directions. A standard 10 BAF (basal area factor) prism was used to measure basal area $\left(\mathrm{m}^{2} / \mathrm{ha}\right)$ of trees from the center of each site; trees were classified as either hardwood or conifer. An ocular tube with cross hairs was used to quantify canopy closure (yes/no) above the site, $5 \mathrm{~m}$ from the site in the cardinal directions, and $10 \mathrm{~m}$ from the site in the cardinal directions [30]. Additionally, a 2-m cover pole was used to measure visual obstruction [31]. The cover pole was placed at each site and viewed from a height of $1 \mathrm{~m}$ at distances of $5 \mathrm{~m}$ and $10 \mathrm{~m}$ in the 4 cardinal directions.

To understand the effects of habitat on fawn survival at broader spatial scales, we constructed a geographic information system in ArcGIS [32] using high-resolution

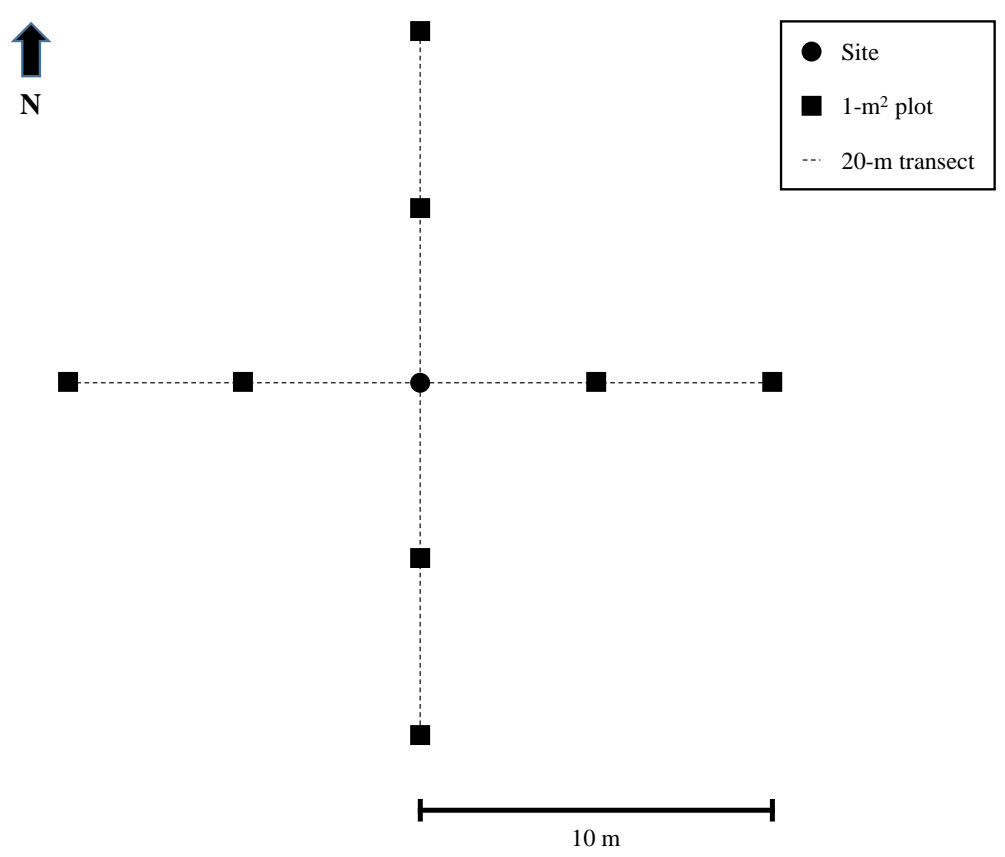

Figure 1. Habitat sampling scheme at white-tailed deer fawn birth and random sites in the Red Hills region, FL and GA, USA, 2012-2013. 
aerial photographs [33]. The cover type at each site was characterized using [28] classification system. Cover types were grouped into 5 categories: hardwood forest, natural pine, managed (planted) pine, human-influenced (i.e., row crop, other-herbaceous, successional, pasture/hay, and developed open space), and water. ArcGIS Analysis Tools were used to quantify landscape features around sites, including nearest different cover type, distance to the nearest edge (different cover type, road, or water; $\mathrm{m}$ ), nearest edge type (different cover type or road), distance to nearest road $(\mathrm{m})$, and distance to nearest water $(\mathrm{m})$.

Environmental factors such as weather and deer population abundance and structure may influence fawn survival (e.g., [2]). Average ( $\mathrm{cm}$ ) and total days of rainfall were determined from the nearest National Oceanic and Atmospheric Administration monitoring station for fawn birth months (Monticello, Florida for the RP site and Cairo, GA for the DPPP site). We estimated deer relative abundance and structure using a grid of 16 Bushnell 8 MP Trophy Cam trail cameras (Bushnell Outdoor Products, Overland Park, KS; = $333 \mathrm{~m}$ spacing, $1000 \mathrm{~m} \times 1000 \mathrm{~m}$ ) simultaneously on each half (coyote removal or not) of each study site. Cameras were baited with corn [34] and remained at each site for one week before they were rotated to the other study site. Camera surveys occurred one time/year (2012-2013) during the deer fawning season (May-July), when coyotes are most likely to prey on fawns, and most active as they are raising pups [25]. Deer relative abundance was recorded as deer captured/site/year, and structure expressed as buck:doe and fawn:doe ratios.

\subsection{Analyses}

Kaplan-Meier daily survival curves were determined for all fawns through 12 weeks of age. A Cox proportional hazards model [35] and likelihood ratio test $(\mathrm{G})$ were used to examine differences in fawn survival rates between coyote-removal and non-removal sites, and to examine differences in coyote-predation rates between site types. Statistical significance was concluded at $\mathrm{P}<0.100$. This value was used rather than the more common $\mathrm{P} \leq 0.050$ to minimize the probability of making a Type II error [36].

We assessed birth-site characteristics affecting fawn daily survival rates (DSR) in an Information-Theoretical framework using a nest survival model. Because fawns move very little in the first few weeks of life [37], habitat characteristics at the birth site may influence fawn susceptibility to predation. Regression models were developed relating birth-site characteristics to DSR.

Further, to understand the importance of habitat at multiple scales on birth-site selection, we employed case-control logistic regression. Each matched set consisted of a birth site (case) and paired site (control). Additionally, to determine differences (e.g., microhabitat, landscape, and environmental characteristics) between birth sites for fawns that survived and fawns that died, we used a non-paired logistic regression. All analyses were conducted using Program R [38].

Based on the literature, prior knowledge and field experience, and project goals, we developed sets of a priori single- and multiple-variable candidate models consisting of 
microhabitat, landscape, and environmental characteristics influencing survival, and overall and coyote-specific fawn predation mortality. When a model contained correlated variables $(r>0.70$; [39]), the model was excluded from consideration. Individual models were limited to 3 predictor variables to reduce the likelihood of over-fitting. We examined $\mathrm{AIC}_{\mathrm{c}}$ values, $\mathrm{AIC}_{\mathrm{c}}$ differences $\left(\Delta \mathrm{AIC}_{\mathrm{c}}\right)$, and Akaike weights $\left(w_{i}\right)$ for models with different combinations of predictor variables, and considered models with $\Delta \mathrm{AIC}_{c}$ $<2$ supported [40]. Where multiple models were supported, we used model averaging to increase precision of inference. When $90 \%$ confidence intervals (CI) for variables within supported models overlapped with zero, we considered them to have a weak effect on the dependent variable and to be uninformative [41]. When a $90 \%$ CI was $>0$, we indicate that the variable was selected for and $<0$ against. Fawns that could not be found after a birth event $(n=18)$ were censored from survival analyses because fate could not be determined. For brevity and clarity, we only present results of supported models. A complete list of models evaluated can be found in [42].

\section{Results}

\subsection{Survival}

We captured 37 adult female deer from which we recorded 48 births. Of the 48 fawns born, we documented the survival and fate of 30 individuals through 12 weeks of age (Figure 2; 22 in 2012 and 8 in 2013; 10 on coyote-removal and 20 on non-removal sites). The leading cause of fawn mortality $(n=20 ; 67 \%)$ was predation $(n=19 ; 95 \%)$, with only 1 fawn having died from another cause (suspected deformity). Of the fawns

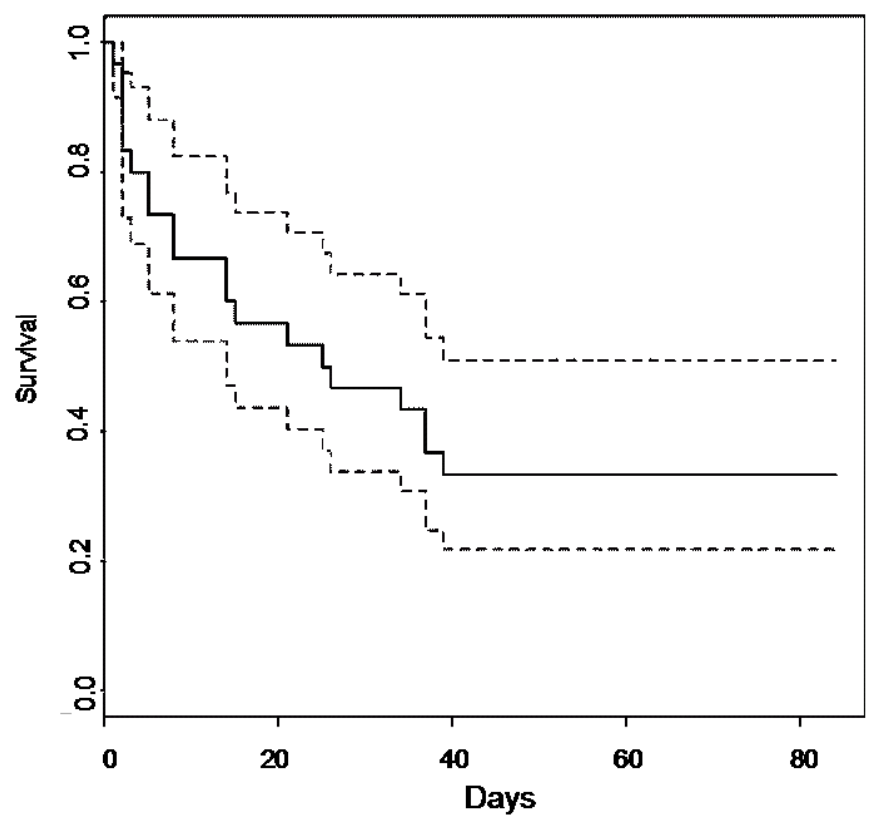

Figure 2. Kaplan-Meier curve for daily survival rates (estimate [solid], $90 \%$ CI [dashed]) of white-tailed deer fawns in the Red Hills region, FL and GA, USA, 2012-2013. 
that died from predation, coyote predation was most important $(\mathrm{n}=14 ; 74 \%)$, followed by bobcat $(\mathrm{n}=3 ; 16 \%)$, and red-imported fire ants (Solenopsis invicta; $\mathrm{n}=2$ [twins]; $11 \%$; suspected but could have been scavenged). Fawn survival rates were greater on coyote-removal sites compared with non-removal sites for all fawns (Figure 3), with $50 \%(5 / 10)$ and $25 \%(5 / 20)$ of fawns surviving 12 weeks on coyote-removal and nonremoval sites, respectively. Survival rates of fawns ultimately predated by coyotes was greater $\left(\mathrm{G}_{0.10,1}=2.77 ; \mathrm{P}=0.096\right)$ on coyote-removal than non-removal sites, with $40 \%$ $(4 / 10)$ and $50 \%(10 / 20)$ of fawns predated by coyotes within 12 weeks on coyote-removal and non-removal sites, respectively.

When assessing factors at birth sites $(\mathrm{n}=30)$ affecting DSR of all fawns, one model was supported. Fawn survival was greater at sites with lower total basal area, and when in or near hardwood, natural pine, and managed (planted) pine cover types (Table 1 and Table 2). For coyote-predated fawns, three birth-site models were supported. Coyote-predated fawn survival was lower at sites with greater hardwood and total basal area, and when there was a closed canopy directly over the birth site (Table 1 and Table 2).

\subsection{Site Selection}

At birth sites for all and fawns predated by coyotes, the same 2 models assessing birthsite selection were supported. Canopy cover within $10 \mathrm{~m}$ of fawn birth sites was selected for, and closed canopy cover directly over the birth site had weak selection against (Table 3 and Table 4).

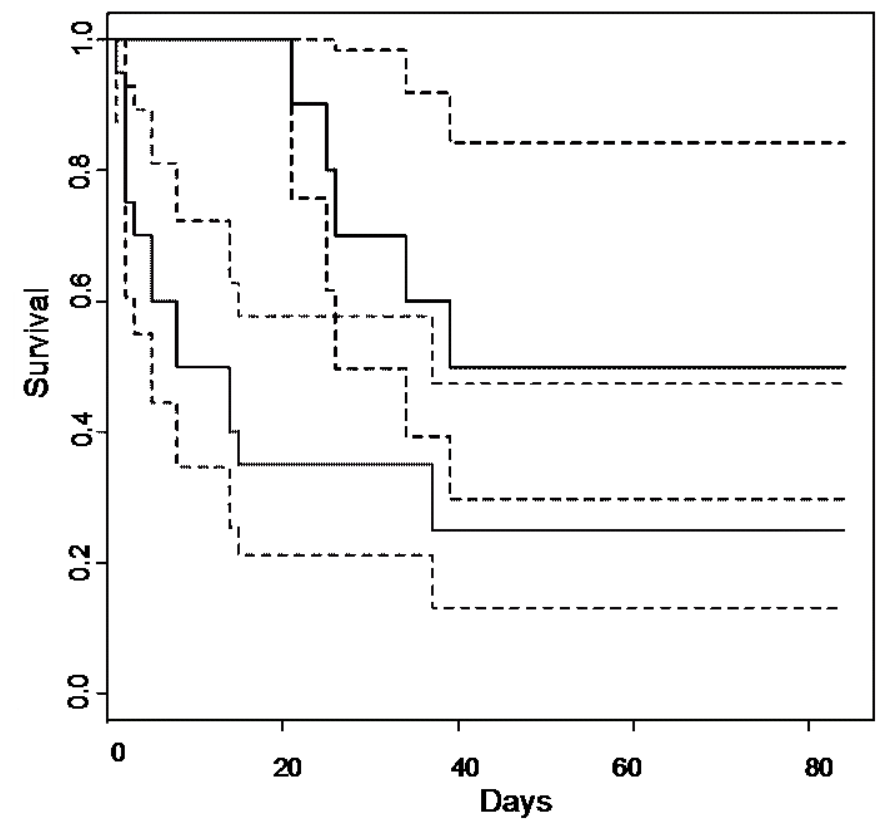

Figure 3. Kaplan-Meier curves for daily survival rates (estimate [solid], 90\% CI [dashed]) of white-tailed deer fawns on coyote-removal (black) and non-removal (grey) sites $\left(\mathrm{G}_{0.10,1}=3.92 ; \mathrm{P}=0.048\right)$ in the Red Hills region, FL and GA, USA, 2012-2013. 
When comparing birth-site characteristics for fawns that died of any cause to those that survived, 5 models were supported. Birth sites of fawns that died had less shrub cover within $5 \mathrm{~m}$ than fawns that survived. Comparing birth-site characteristics for

Table 1. Supported models ${ }^{\mathrm{a}}$ of factors affecting white-tailed deer fawn daily survival rates at birth sites in the Red Hills region, FL and GA, USA, 2012-2013.

\begin{tabular}{cccccc}
\hline Birth Sites & Model & $\mathrm{K}$ & $\mathrm{AIC}_{\mathrm{c}}$ & $\Delta \mathrm{AIC}_{\mathrm{c}}$ & $w_{i}$ \\
\hline \multirow{2}{*}{ All Fawns } & TotalBA $^{\mathrm{b}}+$ CoverType $^{\mathrm{c}}+$ & 8 & 454.338 & 0.000 & 1.000 \\
& NearCoverType $^{\mathrm{d}}$ & 2 & 199.523 & 0.000 & 0.284 \\
Coyote-Predated Fawns & HwBA $^{\mathrm{e}}$ & 2 & 200.353 & 0.839 & 0.188 \\
& TotalBA $^{*}$ & 2 & 200.815 & 1.291 & 0.149 \\
\hline
\end{tabular}

${ }^{\mathrm{a}}$ Akaike's Information Criterion [AIC]; $\Delta \mathrm{AIC}_{\mathrm{c}} \leq 2$; ${ }^{\mathrm{b}} \mathrm{Total}$ basal area at site $\left(\mathrm{m}^{2} / \mathrm{ha}\right)$; ${ }^{\mathrm{c} C o v e r}$ type in which fawn was found; includes hardwood, managed (planted) pine, natural pine, human-influenced, and water cover types; ${ }^{\mathrm{d} C o v e r}$ type closest to cover in which fawn was found; ${ }^{\mathrm{e}}$ Basal area of hardwood trees at site $\left(\mathrm{m}^{2} / \mathrm{ha}\right) ;{ }^{\mathrm{f}} \mathrm{Closed}$ canopy at site (Yes/No).

Table 2. Coefficients from supported models of factors affecting white-tailed deer fawn daily survival rates at birth sites in the Red Hills region, FL and GA, USA, 2012-2013.

\begin{tabular}{|c|c|c|c|c|c|}
\hline \multirow[b]{2}{*}{ Birth Sites } & \multirow[b]{2}{*}{ Variable } & \multirow[b]{2}{*}{$\beta$} & \multirow[b]{2}{*}{ SE } & \multicolumn{2}{|c|}{$90 \% \mathrm{CI}$} \\
\hline & & & & Lower & Upper \\
\hline \multirow[t]{7}{*}{ All Fawns } & TotalBA $^{\mathrm{a}}$ & -0.073 & 0.009 & -0.087 & -0.059 \\
\hline & CoverType $^{\mathrm{b}}(\mathrm{HW})$ & 8.064 & 0.793 & 6.760 & 9.367 \\
\hline & CoverType (MP) & 5.235 & 0.743 & 4.014 & 6.457 \\
\hline & CoverType (NP) & 0.912 & 0.548 & 0.011 & 1.813 \\
\hline & NearCoverType ${ }^{c}(\mathrm{HW})$ & -5.213 & 0.532 & -6.088 & -4.339 \\
\hline & NearCoverType (MP) & -6.724 & 0.917 & -8.231 & -5.216 \\
\hline & NearCoverType (NP) & -2.836 & 0.647 & -3.901 & -1.711 \\
\hline \multirow[t]{3}{*}{ Coyote-Predated Fawns } & $\mathrm{HwBA}^{\mathrm{d}}$ & -0.011 & 0.012 & -0.032 & -0.014 \\
\hline & TotalBA & -0.007 & 0.011 & -0.031 & -0.013 \\
\hline & CCCenter $^{\mathrm{e}}$ & -0.368 & 0.684 & -2.200 & -0.868 \\
\hline
\end{tabular}

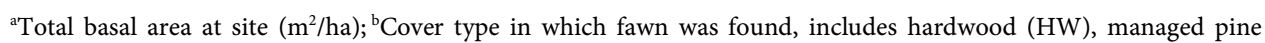
(MP), and natural pine (NP) cover types; ${ }^{\circ}$ Cover type closest to cover in which fawn was found; ${ }^{d}$ Basal area of hardwood trees at site $\left(\mathrm{m}^{2} / \mathrm{ha}\right)$; ${ }^{\mathrm{e}} \mathrm{Closed}$ canopy at site (Yes/No).

Table 3. Supported models ${ }^{a}$ of factors affecting white-tailed deer birth-site selection in the Red Hills region, FL and GA, USA, 2012-2013.

\begin{tabular}{cccccc}
\hline Birth Sites & Model & $\mathrm{K}$ & $\mathrm{AIC}_{\mathrm{c}}$ & $\Delta \mathrm{AIC}_{\mathrm{c}}$ & $w_{i}$ \\
\hline All Fawns & CCCenter $+\mathrm{CC} 10 \mathrm{mAv}^{\mathrm{c}}$ & 2 & 25.232 & 0.000 & 0.709 \\
& $\mathrm{CC10mAv}$ & 1 & 27.015 & 1.781 & 0.291 \\
$\begin{array}{c}\text { Coyote-Predated } \\
\text { Fawns }\end{array}$ & CCCenter $+\mathrm{CC} 10 \mathrm{mAv}$ & 2 & 13.687 & 0.000 & 0.269 \\
& $\mathrm{CC} 10 \mathrm{mAv}$ & 1 & 14.110 & 0.423 & 0.218 \\
\hline
\end{tabular}

${ }^{\mathrm{a}}$ Akaike's Information Criterion [AIC]; $\Delta \mathrm{AIC}_{\mathrm{c}} \leq 2$; ${ }^{\mathrm{b}}$ Closed canopy at site (Yes/No); ${ }^{\mathrm{c} C a n o p y}$ closure within $10 \mathrm{~m}$ of site (\%). 
fawns that were predated by coyotes to those that survived, 2 models were supported. Birth sites of fawns predated by coyotes had less grass cover at and within $10 \mathrm{~m}$, and greater herbaceous cover within $10 \mathrm{~m}$ than fawns that survived (Table 5 and Table 6).

Table 4. Coefficients from supported models of factors affecting white-tailed deer birth-site selection in the Red Hills region, FL and GA, USA, 2012-2013.

\begin{tabular}{ccccccc}
\hline \multirow{2}{*}{ Birth Sites } & & & & \multicolumn{2}{c}{$90 \%$ CI } \\
\cline { 5 - 6 } & Vall Fawns & & $\beta$ & SE & Lower & Upper \\
\hline \multirow{2}{*}{ Coyote-Predated Fawns } & CCCenter $^{\mathrm{a}}(\mathrm{Yes})$ & -2.200 & 1.352 & -4.420 & 0.029 \\
& CC10mAv $^{\mathrm{b}}$ & 9.622 & 4.800 & 1.728 & 17.516 \\
& CC10mAv & 9.056 & 5.632 & -0.207 & 18.320 \\
& CCCenter $(\mathrm{Yes})$ & -2.475 & 1.823 & -5.474 & 0.523 \\
\hline
\end{tabular}

${ }^{\mathrm{a}}$ Closed canopy at site (Yes/No); ${ }^{\mathrm{b}}$ Canopy closure within $10 \mathrm{~m}$ of site (\%).

Table 5. Supported models ${ }^{\mathrm{a}}$ of factors affecting white-tailed deer birth-site differences between fawns living and dying (all causes and coyote-predation) in the Red Hills region, FL and GA, USA, 2012-2013.

\begin{tabular}{|c|c|c|c|c|c|}
\hline Birth Sites & Model & $\mathrm{K}$ & $\mathrm{AIC}_{\mathrm{c}}$ & $\Delta \mathrm{AIC}_{\mathrm{c}}$ & $w_{i}$ \\
\hline \multirow[t]{5}{*}{ All Fawns } & $\mathrm{QS}_{\mathrm{mAv}}^{\mathrm{b}}$ & 2 & 38.276 & 0.000 & 0.079 \\
\hline & $\mathrm{QS} 5 \mathrm{mAv}+\mathrm{QH} 5 \mathrm{mAv}{ }^{\mathrm{c}}$ & 3 & 38.388 & 0.112 & 0.075 \\
\hline & $\mathrm{CP} 10 \mathrm{mAv} \mathrm{v}^{\mathrm{d}}$ & 2 & 38.980 & 0.704 & 0.056 \\
\hline & QGCenter $^{\mathrm{e}}$ & 2 & 39.807 & 1.531 & 0.037 \\
\hline & $\mathrm{QH} 10 \mathrm{mAv} v^{\mathrm{f}}$ & 2 & 39.997 & 1.720 & 0.034 \\
\hline \multirow[t]{2}{*}{ Coyote-Predated Fawns } & $\mathrm{QG} 10 \mathrm{mAv} v^{\mathrm{g}}+\mathrm{QH} 10 \mathrm{mAv}$ & 3 & 28.181 & 0.000 & 0.259 \\
\hline & QGCenter & 2 & 29.636 & 1.456 & 0.125 \\
\hline
\end{tabular}

${ }^{\mathrm{a}}$ Akaike's Information Criterion [AIC]; $\Delta \mathrm{AIC}_{\mathrm{c}} \leq 2$; ${ }^{\mathrm{b}}$ Shrub cover within $5 \mathrm{~m}$ of site (\%); ${ }^{\mathrm{c}}$ Total herbaceous cover within $5 \mathrm{~m}$ of site (\%); ${ }^{\mathrm{d} C o v e r}$ pole reading within $10 \mathrm{~m}$ of site (\%); ${ }^{\mathrm{e}} \mathrm{Grass}$ cover at site center (\%); ${ }^{\mathrm{f}}$ Total herbaceous cover within $10 \mathrm{~m}$ of site (\%); ${ }^{\mathrm{g}} \mathrm{Grass}$ cover within $10 \mathrm{~m}$ of site (\%).

Table 6. Coefficients from supported models of factors affecting white-tailed deer birth-site differences between fawns living and dying (all causes and coyote-predation) in the Red Hills region, FL and GA, USA, 2012-2013.

\begin{tabular}{clcccc}
\hline \multirow{2}{*}{ Birth Sites } & & & & \multicolumn{2}{c}{$90 \%$ CI } \\
\cline { 5 - 6 } All Fawns & Variable & $\beta$ & SE & Lower & Upper \\
& QS5mAv $^{\mathrm{a}}$ & -0.162 & 0.095 & -0.318 & -0.007 \\
& QH5mAv $^{\mathrm{b}}$ & 0.040 & 0.030 & -0.009 & 0.089 \\
& CP10mAv $^{\mathrm{c}}$ & 0.345 & 0.218 & -0.013 & 0.704 \\
& QGCenter $^{\mathrm{d}}$ & -0.026 & 0.019 & -0.057 & 0.006 \\
& QH10mAv $^{\mathrm{e}}$ & 0.030 & 0.024 & -0.010 & 0.070 \\
Coyote-Predated Fawns & QG10mAv $^{\mathrm{f}}$ & -0.170 & 0.093 & -0.324 & -0.017 \\
& QH10mAv & 0.105 & 0.050 & 0.023 & 0.187 \\
& QGCenter & -0.115 & 0.058 & -0.210 & -0.019 \\
\hline
\end{tabular}

${ }^{\mathrm{a}} \mathrm{Shrub}$ cover within $5 \mathrm{~m}$ of site (\%); ${ }^{\mathrm{b}}$ Total herbaceous cover within $5 \mathrm{~m}$ of site (\%); ${ }^{\mathrm{c}}$ Cover pole reading within $10 \mathrm{~m}$ of site (\%); ${ }^{\mathrm{d}}$ Grass cover at site center (\%); ${ }^{\mathrm{e}}$ Total herbaceous cover within $10 \mathrm{~m}$ of site (\%); ${ }^{\mathrm{f}}$ Grass cover within $10 \mathrm{~m}$ of site (\%). 


\section{Discussion}

We quantified coyote predation effects on deer fawns in the Red Hills region of Georgia and Florida, and illustrate the role that habitat plays in predation mortality and fawn survival. The greater deer fawn survival on coyote removal sites, and greater coyotepredation rates on non-removal sites, suggests that coyotes may be acting as an additive form of deer mortality [43] [44] [45].

Additionally, our study uniquely examined the relationships between white-tailed deer birth-site selection and fawn survival, particularly in the context of coyote predation, as previous studies emphasized only fawn bed-site selection on survival [46] [47] [48]. Survival for all fawns and those predated by coyotes improved when fawns were born at sites with less total and hardwood basal area, less canopy cover, and in and closer to hardwood, natural pine, and managed (planted) pine cover types. Further, we found that adult female deer whose fawns died of any cause or were predated by coyotes selected for birth-site locations with greater canopy cover directly above. The positive association with hardwoods and increased canopy cover may be due to the presence of nutritious mast [49] [50] that would allow adult deer to forage close to and monitor fawns [37] [51] [52], and escape the summer heat and rain. However, coyotes rely on subtle visual [53] [54] and auditory [55] [56] cues to detect prey, and may key in on certain doe behaviors that indicate fawn presence [57]. The increased canopy cover and lower basal area found at birth sites may create a sparsely vegetated understory that provides unsuitable hiding cover for fawns, facilitate coyote movements across the landscape, and allow ambush of does and fawns. Our finding that fawn survival was positively related to birth-site shrub and grass cover supports this conclusion.

Because survival was lower and coyote predation rates were greater for fawns born at sites with greater hardwood and total basal area, we expected fawns born in pine communities would have increased survival, as these areas are often characterized by less basal area and more cover in the form of shrub and herbaceous species [28]. We found that being born in and near natural and managed (planted) pine stands had positive impacts on fawn survival. Both types of pine stands on our sites received regular burning, and managed pine stands were thinned. This created more open canopies, and relatively abundant herbaceous/ground and shrub cover, particularly in the natural pine stands. However, natural pine communities may mimic a savannah-like system that is similar to more open habitats preferred by coyotes [58] [59] [60], a characteristic that may increase coyote predation success. Although managed pine forests may not provide appropriate fawning cover in the form of a balanced mixture of shrub and herbaceous species, neither does it provide sufficient cover or foraging habitat for coyotes [58] [61]. The structure of these managed pine forests may enhance adult female deer detection of predators [62], and provide time to protect fawns and escape coyote predation attempts.

The unique matrix of upland pine and hardwood bottoms characterizing the Red Hills region may be more similar to the prairies in which coyotes evolved their hunting strategies, and have created a landscape that facilitates coyote predation [18]. In other 
areas within the more densely forested Southeast, coyotes may not have the same variety and composition of cover types to exploit [4] [16] [63] [64], possibly accounting for the lack of importance of habitat to fawn survival in those other areas.

Recent studies suggest that managing for cover or habitat generally may not mitigate coyote predation effects [10] [48] [65], whereas we found that habitat played an important role in deer fawn survival. Although studies examining the relationship between habitat management and deer fawn survival exist [66] [67], few directly linked habitat structure and composition to fawn survival [48] [68] [69], and fewer linked habitat to coyote predation of fawns. Unlike the hierarchical approach that [70] recommends when attempting to understand predation risk, studies that examine the relationship between habitat variables and fawn survival tend to consider microhabitat and the landscape separately [10] [18] [48], rather than simultaneously as a predator might when it seeks prey. By studying microhabitat and the landscape simultaneously, we found that habitat at multiple levels was important to fawn survival. Studies that failed to take this same approach have often had conflicting conclusions (e.g., [20] [71]); suggesting that more research is necessary, particularly in the Southeast where such information is often lacking.

\section{Conclusions and Implications}

Coyote predation in the Red Hills region is an important source of deer fawn mortality. Despite the long tradition of predator removal in land management programs in this region, and short-term benefits of coyote removal, deer fawn survival may not be significantly affected if removal is not balanced by habitat management programs that promote fawn cover. Although coyote removal did enhance fawn survival rates, habitat also played a role in fawn survival. Because the Red Hills region spans two states where conflicting deer management goals may exist and contains primarily privately-owned land, the potentially uneven application of deer management programs may not have the overall desired effects on deer populations. If current management practices do not take into account the habitat effects on coyote predation success, deer populations may be negatively impacted. We suggest practices such as thinning and group selection cutting that reduce overstory basal area, particularly hardwoods, and canopy closure be employed, because they likely promote herbaceous/ground and shrub cover, and possibly mast production.

\section{Acknowledgements}

We thank E. Hellgren, R. McCleery, and J. Tirpak for review comments and contributions to this manuscript. W. Pine assisted with analyses and programming in Program R. Funding and support were provided by The University of Florida Foundation, University of Florida, and the Florida Fish and Wildlife Conservation Commission.

\section{References}

[1] Howze, M.B., Conner, L.M., Warren, R.J. and Miller, K.V. (2009) Predator Removal and 
White-Tailed Deer Recruitment in Southwestern Georgia. Proceedings of the Annual Conference of the Southeastern Association of Fish and Wildlife Agencies, Southeastern Association of Fish and Wildlife Agencies, Jackson, 63, 17-20.

[2] Kilgo, J.C., Ray, H.S., Ruth, C. and Miller, K.V. (2010) Can Coyotes Affect Deer Populations in Southeastern North America? Journal of Wildlife Management, 74, 929-933. http://dx.doi.org/10.2193/2009-263

[3] Kilgo, J.C., Ray, H.S., Vukovich, M., Goode, M.J. and Ruth, C. (2012) Predation by Coyotes on White-Tailed Deer Neonates in South Carolina. Journal of Wildlife Management, 76, 1420-1430. http://dx.doi.org/10.1002/jwmg.393

[4] Gompper, M.E. (2002) Top Carnivores in the Suburbs? Ecological and Conservation Issues Raised by Colonization of Northeastern North America by Coyotes. BioScience, 52, 185 190. http://dx.doi.org/10.1641/0006-3568(2002)052[0185:TCITSE]2.0.CO;2

[5] Turner, M.M., Rockhill, A.P., DePerno, C.S., Jenks, J.A., Klaver, R.W., Jarding, A.R., Grovenburg, T.W. and Pollock, K.H. (2011) Evaluating the Effect of Predators on White-Tailed Deer: Movement and Diet of Coyotes. Journal of Wildlife Management, 75, 905-912. http://dx.doi.org/10.1002/jwmg.109

[6] Shea, S.M. and Osborne, J.S. (1995) Quality whitetails. Stackpole Books, Mechanicsburg.

[7] Beasom, S.L. (1974) Relationships between Predator Removal and White-Tailed Deer Net Productivity. Journal of Wildlife Management, 38, 854-859.

http://dx.doi.org/10.2307/3800056

[8] Beasom, S.L. (1977) Predation on Big Game and Its Management. Great Plains Wildlife Damage Control Workshop Proceedings, University of Nebraska, Lincoln, 236, 259-266.

[9] Wade, D.A. (1981) Coyote Management: A Rationale for Population Reduction. Great Plains Wildlife Damage Control Workshop Proceedings, University of Nebraska, Lincoln, 146, 259266.

[10] Kilgo, J.C., Vukovich, M., Ray, H.S., Shaw, C.E. and Ruth, C. (2014) Coyote Removal, Understory Cover, and Survival of White-Tailed Deer Neonates. Journal of Wildlife Management, 78, 1261-1271. http://dx.doi.org/10.1002/jwmg.764

[11] Connolly, G.E. and Longhurst, W.M. (1975) The Effects of Control on Coyote Populations. Bulletin of the Division of Agricultural Sciences, University of California, Berkeley, 1-37.

[12] Connolly, G.E. (1978) Predator Control and Coyote Populations: A Review of Simulation Models. In: Bekoff, M., Ed., Coyotes. Biology, Behavior, and Management, Academic Press, New York, 327-345.

[13] Henke, S.E. and Bryant, F.C. (1999) Effects of Coyote Removal on the Faunal Community in Western Texas. Journal of Wildlife Management, 63, 1066-1081. http://dx.doi.org/10.2307/3802826

[14] Gese, E.M. (2005) Demographic and Spatial Responses of Coyotes to Changes in Food and Exploitation. Proceedings of the Wildlife Damage Management Conference, 11, 271-285.

[15] VanGilder, C.L., Woods, G.R. and Miller, K.V. (2009) Effects of an Intensive Predator Removal on White-Tailed Deer Recruitment in Northeastern Alabama. Proceedings of the Annual Conference of the Southeastern Association of Fish and Wildlife Agencies, 63, 1116.

[16] Chitwood, M.C., Lashley, M.A., Kilgo, J.C., Moorman, C.E. and DePerno, C.S. (2015) White-Tailed Deer Population Dynamics and Adult Female Survival in the Presence of a Novel Predator. Journal of Wildlife Management, 79, 211-219. http://dx.doi.org/10.1002/jwmg.835

[17] Gulsby, W.D., Killmaster, C.H., Bowers, J.W., Kelly, J.D., Sacks, B.N., Statham, M.J. and 
Miller, K.V. (2015) White-Tailed Deer Fawn Recruitment before and after Experimental Coyote Removals in Central Georgia. Wildlife Society Bulletin, 39, 248-255. http://dx.doi.org/10.1002/wsb.534

[18] Rohm, J.H., Nielsen, C.K. and Woolf, A. (2007) Survival of White-Tailed Deer Fawns in Southern Illinois. Journal of Wildlife Management, 71, 851-860.

http://dx.doi.org/10.2193/2006-027

[19] Grovenburg, T.W., Swanson, C.C., Jaques, C.N., Klaver, R.W., Brinkman, T.J., Burris, B.M., Deperno, C.S. and Jenks, J.A. (2011) Survival of White-Tailed Deer Neonates in Minnesota and South Dakota. Journal of Wildlife Management, 75, 213-220. http://dx.doi.org/10.1002/jwmg.20

[20] Grovenburg, T.W., Klaver, R.W. and Jenks, J.A. (2012) Survival of White-Tailed Deer Fawns in the Grasslands of the Northern Great Plains. Journal of Wildlife Management, 76, 944956. http://dx.doi.org/10.1002/jwmg.339

[21] Tall Timbers Research Station and Land Conservancy (2014) What Is the Red Hills Region? http://talltimbers.org/red-hills-region/

[22] Bowman, J.L. and Jacobson, H.A. (1998) An Improved Vaginal Implant Transmitter for Locating White-Tailed Deer Birth Sites and Fawns. Wildlife Society Bulletin, 26, 295-298.

[23] DelGiudice, G.D., Fieberg, J., Riggs, M.R., Carstensen-Powell, M. and Pan, W. (2006) A Long-Term Age-Specific Survival Analysis of Female White-Tailed Deer. Journal of Wildlife Management, 70, 1556-1568. http://dx.doi.org/10.2193/0022-541X(2006)70[1556:ALASAO]2.0.CO;2

[24] Carstensen, M., DelGiudice, G.D., Sampson, B.A. and Kuehn, D.W. (2009) Survival, Birth Characteristics, and Cause-Specific Mortality of White-Tailed Deer Neonates. Journal of Wildlife Management, 73, 175-183. http://dx.doi.org/10.2193/2006-107

[25] Harrison, D.J. and Gilbert, J.R. (1985) Denning Ecology and Movements of Coyotes in Maine during Pup Rearing. Journal of Mammalogy, 66, 712-719. http://dx.doi.org/10.2307/1380797

[26] Labisky, R.F. and Boulay, M.C. (1998) Behaviors of Bobcats Preying on White-Tailed Deer in the Everglades. American Midland Naturalist, 139, 275-281. http://dx.doi.org/10.1674/0003-0031(1998)139[0275:BOBPOW]2.0.CO;2

[27] Roberts, S.B. (2007) Ecology of White-Tailed Deer and Bobcats on Kiawah Island, South Carolina: Implications for Suburban Habitat Preservation. PhD Dissertation, University of Georgia, Athens.

[28] Southeast Gap Analysis Project (2013) Southeast Gap Analysis Project. http://www.basic.ncsu.edu/segap/

[29] Hays, R.L., Summers, C. and Seitz, W. (1981) Estimating Wildlife Habitat Variables. USDI Fish and Wildlife Service, FWS/OBS-81/47.

[30] Dueser, R.D. and Shugart, H.H. (1978) Microhabitats in a Forest-Floor Small Mammal Fauna. Ecology, 59, 89-98. http://dx.doi.org/10.2307/1936634

[31] Griffith, B. and Youtie, B.A. (1988) Two Devices for Estimating Foliage Density and Deer Hiding Cover. Wildlife Society Bulletin, 16, 206-210.

[32] Environmental Systems Research Institute (2014) ArcGIS for Server 10.2.2. http://www.esri.com/software/arcgis/arcgis-for-desktop

[33] US Geological Survey's Earth Resources Observation and Science Center (2013) http://eros.usgs.gov/\#/About_Us/Customer_Service/Data_Citation

[34] McKinley, W.T., Demarais, S., Gee, K.L. and Jacobson, H.A. (2006) Accuracy of the Camera 
Technique for Estimating White-Tailed Deer Population Characteristics. Proceedings of the Annual Conference of the Southeastern Association of Fish and Wildlife Agencies, 60, 8388.

[35] Murray, D.L. (2006) On Improving Telemetry-Based Survival Estimation. Journal of Wildlife Management, 70, 1530-1543. http://dx.doi.org/10.2193/0022-541X(2006)70[1530:OITSE]2.0.CO;2

[36] Zar, J.H. (1999) Biostatistical Analysis. 4th Edition, Prentice Hall, Upper Saddle River.

[37] Ozoga, J.J., Verme, L.J. and Bienz, C.S. (1982) Parturition Behavior and Territoriality in White-Tailed Deer: Impact on Neonatal Mortality. Journal of Wildlife Management, 46, 111. http://dx.doi.org/10.2307/3808402

[38] R Development Core Team (2013) R: A Language and Environment for Statistical Computing. R Foundation for Statistical Computing, Vienna. http://www.R-project.org

[39] Tirpak, J.M., Giuliano, W.M. and Miller, C.A. (2008) Ruffed Grouse Brood Habitat Selection at Multiple Scales in Pennsylvania: Implications for Survival. Canadian Journal of Zoology, 86, 329-337. http://dx.doi.org/10.1139/Z07-143

[40] Burnham, K.P. and Anderson, D.R. (2002.) Model Selection and Multi-Model Inference: A Practical Information-Theoretic Approach. 2nd Edition, Springer, New York.

[41] Payton, M.E., Greenstone, M.H. and Schenker, N. (2003) Overlapping Confidence Intervals or Standard Error Intervals: What Do They Mean in Terms of Statistical Significance? Journal of Insect Science, 3, 34. http://dx.doi.org/10.1673/031.003.3401

[42] Watine, L.N. (2015) Coyote Predation Effects on White-Tailed Deer Fawns. MS Thesis, University of Florida, Gainesville.

[43] Messier, F., Barrette, C. and Huot, J. (1986) Coyote Predation on a White-Tailed Deer Population in Southern Quebec. Canadian Journal of Zoology, 64, 1134-1136. http://dx.doi.org/10.1139/z86-170

[44] Ballard, W.B., Lutz, D., Keegan, T.W., Carpenter, L.H. and deVos, J.C. (2001) Deer-Predator Relationships: A Review of Recent North American Studies with Emphasis on Mule and Black-Tailed Deer. Wildlife Society Bulletin, 29, 99-115.

[45] Patterson, B.R., MacDonald, B.A., Lock, B.A., Anderson, D.G. and Benjamin, L.K. (2002) Proximate Factors Limiting Population Growth of White-Tailed Deer in Nova Scotia. Journal of Wildlife Management, 66, 511-521. http://dx.doi.org/10.2307/3803184

[46] Huegel, C.N., Dahlgren, R.B. and Gladfelter, H.L. (1986) Bedsite Selection by White-Tailed Deer Fawns in Iowa. Journal of Wildlife Management, 50, 474-480.

http://dx.doi.org/10.2307/3801109

[47] Hyde, K.J., DeYoung, C.A. and Garza, A. (1987) Bed Sites of White-Tailed Deer Fawns in South Texas. Proceedings of the Annual Conference of the Southeastern Association of Fish and Wildlife Agencies, 41, 288-293.

[48] Chitwood, M.C., Lashley, M.A., Kilgo, J.C., Pollock, K.H., Moorman, C.E. and De Perno, C.S. (2015) Do Biological and Bed-Site Characteristics Influence Survival of Neonatal White-Tailed Deer? PLOS ONE, 10, e0119070. http://dx.doi.org/10.1371/journal.pone.0119070

[49] Masters, R.E., Wilson, C.W., Bukenhofer, G.A. and Payton, M.E. (1996) Effects of PineGrassland Restoration for Red-Cockaded Woodpeckers on White-Tailed Deer Forage Production. Wildlife Society Bulletin, 24, 77-84.

[50] Schroeder, R.L. and VanGilder, L.D. (1997) Tests of Wildlife Habitat Models to Evaluate Oak-Mast Production. Wildlife Society Bulletin, 25, 639-646.

[51] Hirth, D.H. (1994) Does and Their Young. In: Gerlach, D., Atwater, S. and Schnell, J., Eds., 
Deer, Stackpole Books, Mechanicsburg, 129-134.

[52] Miller, K.V., Muller, L.I. and Demarais, S. (2003) White-Tailed Deer. In: Feldhamer, G.A. Thompson, B.C. and Chapman, J.A., Eds., Wild Mammals of North America: Biology, Management, and Conservation, 2nd Edition, the Johns Hopkins University Press, Baltimore, 906-930.

[53] Wells, M.C. and Lehner, P.N. (1978) The Relative Importance of the Distance Senses in Coyote Predatory Behavior. Animal Behavior, 26, 251-258. http://dx.doi.org/10.1016/0003-3472(78)90025-8

[54] Mason, J.R. and Burns, R.J. (1997) Coyote Responsiveness to Novel Visual Stimuli. Journal of Wildlife Research, 2, 6-8.

[55] Wells, M.C. and Bekoff, M. (1982) Predation by Wild Coyotes: Behavioral and Ecological Analyses. Journal of Mammalogy, 63, 118-127. http://dx.doi.org/10.2307/1380678

[56] Gese, E.M., Ruff, R.L. and Crabtree, R.L. (1996) Foraging Ecology of Coyotes (Canis latrans): The Influence of Extrinsic Factors and a Dominance Hierarchy. Canadian Journal of Zoology, 74, 769-783. http://dx.doi.org/10.1139/z96-089

[57] Byers, J.A. and Byers, K.Z. (1983) Do Pronghorn Mothers Reveal the Locations of Their Hidden Fawns? Behavioral Ecology and Sociobiology, 13, 147-156. http://dx.doi.org/10.1007/BF00293804

[58] Holzman, S., Conroy, M.J. and Pickering, J. (1992) Home Range, Movements, and Habitat Use of Coyotes in Southcentral Georgia. Journal of Wildlife Management, 56, 139-146. http://dx.doi.org/10.2307/3808801

[59] Kamler, J.F., Ballard, W.B., Lemons, P.R., Gilliand, R.L. and Mote, K. (2005) Home Range and Habitat Use of Coyotes in an Area of Native Prairie, Farmland and CRP Fields. American Midland Naturalist, 153, 396-404. http://dx.doi.org/10.1674/0003-0031(2005)153[0396:HRAHUO]2.0.CO;2

[60] Schrecengost, J.D., Kilgo, J.C., Ray, H.S. and Miller, K.V. (2009) Home Range, Habitat Use and Survival of Coyotes in Western South Carolina. American Midland Naturalist, 162, 346-355. http://dx.doi.org/10.1674/0003-0031-162.2.346

[61] Kamler, J.F. and Gipson, P.S. (2000) Space and Habitat Use by Resident and Transient Coyotes. Canadian Journal of Zoology, 78, 2106-2111. http://dx.doi.org/10.1139/z00-153

[62] LaGory, K.E. (1987) The Influence of Habitat and Group Characteristics on the Alarm and Flight Response of White-Tailed Deer. Animal Behavior, 35, 20-25. http://dx.doi.org/10.1016/S0003-3472(87)80206-3

[63] Litvaitis, J.A. and Shaw, J.H. (1980) Coyote Movements, Habitat Use, and Food Habits in Southwestern Oklahoma. Journal of Wildlife Management, 44, 62-68. http://dx.doi.org/10.2307/3808351

[64] Kays, R.W., Gompper, M.E. and Ray, J.C. (2008) Landscape Ecology of Eastern Coyotes Based on Large-Scale Estimates of Abundance. Ecological Applications, 18, 1014-1027. http://dx.doi.org/10.1890/07-0298.1

[65] Chitwood, M.C. (2014) White-Tailed Deer Population Dynamics in the Presence of a Novel Predator. PhD Dissertation, North Carolina State University, Raleigh.

[66] O’Brien, C.S., Krausman, P.R., Boyd, H.M., Ballard, W.B., Cunningham, S.C. and Devos, J.C. (2010) Influence of Coyotes on Habitat Use by Mule Deer Following a Wildfire. California Fish and Game, 96, 7-22.

[67] Bergman, E.J., Bishop, C.J., Freddy, D.J., White, G.C. and Doherty, P.F. (2014) Habitat Management Influences Overwinter Survival of Mule Deer Fawns in Colorado. Journal of Wildlife Management, 78, 448-455. http://dx.doi.org/10.1002/jwmg.683 
[68] Lomas, L.A. and Bender, L.C. (2007) Survival and Cause-Specific Mortality of Neonatal Mule Deer Fawns, North-Central New Mexico. Journal of Wildlife Management, 71, 884894. http://dx.doi.org/10.2193/2006-203

[69] Hiller, T.L., Campa, H., Winterstein, S.R. and Rudolph, B.A. (2008) Survival and Space Use of Fawn White-Tailed Deer in Southern Michigan. American Midland Naturalist, 159, 403412. http://dx.doi.org/10.1674/0003-0031(2008)159[403:SASUOF]2.0.CO;2

[70] Brown, A.L. and Litvaitis, J.A. (1995) Habitat Features Associated with Predation of New England Cottontails: What Scale Is Appropriate? Canadian Journal of Zoology, 73, 10051011. http://dx.doi.org/10.1139/z95-120

[71] Vreeland, J.K., Diefenbach, D.R. and Wallingford, B.D. (2004) Survival Rates, Mortality Causes, and Habitats of Pennsylvania White-Tailed Deer Fawns. Wildlife Society Bulletin, 32, 542-553. http://dx.doi.org/10.2193/0091-7648(2004)32[542:SRMCAH]2.0.CO;2

Submit or recommend next manuscript to SCIRP and we will provide best service for you:

Accepting pre-submission inquiries through Email, Facebook, LinkedIn, Twitter, etc.

A wide selection of journals (inclusive of 9 subjects, more than 200 journals)

Providing 24-hour high-quality service

User-friendly online submission system

Fair and swift peer-review system

Efficient typesetting and proofreading procedure

Display of the result of downloads and visits, as well as the number of cited articles

Maximum dissemination of your research work

Submit your manuscript at: http://papersubmission.scirp.org/

Or contact nr@scirp.org 